\title{
ANALISIS LOYALITAS KONSUMEN MUSLIM TERHADAP STARBUCKS COFFEE PASCA DUKUNGAN STARBUCKS TERHADAP LGBT
}

\author{
Muhammad Reza ${ }^{1}$ \\ reza58300@gmail.com \\ Saparuddin Siregar ${ }^{2}$ \\ saparuddinss@yahoo.com \\ Marliyah $^{3}$ \\ marliyah@uinsu.ac.id \\ 1, 2, 3 UIN Sumatera Utara Medan
}

\begin{abstract}
Starbucks as well as other companies requires loyalty from its customers to increase the quantity of sales. However, it seems that Starbucks does not care about the loyalty of Muslim customers. This is evident from the Starbucks support campaign for LGBT which is clearly the opposite of Islamic teachings. Because, if Muslims are loyal to Starbucks who are known to support LGBT, it means that Muslims play a role in supporting LGBT. The purpose of this study is to find out Muslim consumer loyalty to Starbucks after Starbucks supported LGBT and also to find out Muslim consumers' responses to Starbucks for providing support Starbucks Coffee in the LGBT community. This study was conducted using qualitative methods. In this study the authors found that Starbucks support for LGBT is an act that violates business ethics in the scope of social responsibility. Moreover LGBT is a for acts that are forbidden in Islam. So Starbucks support for LGBT actions received a positive response from Muslim consumers. From informants who were questioned there was not one informant who agreed with Starbucks Coffee's support for LGBT. 3 of the 5 informants lost their loyalty to Starbucks and reluctant to go back to Starbucks.
\end{abstract}

Keywords: Loyality,Muslim Consumers,Starbucks Coffee,Support, and LGBT

\begin{abstract}
Abstrak
Starbucks sama halnya dengan perusahaan lain memerlukan adanya loyalitas dari pelanggannya untuk meningkatkan kuantitas penjualannya.Akan tetapi,sepertinya Starbucks tidak begitu memperdulikan adanya loyalitas dari pelanggan muslim.Hal ini terbukti dari dilakukannya kampanye dukungan Starbucks terhadap LGBT yang jelas-jelas bertolak belakang dari ajaran agama Islam.Karena,jika umat Islam loyal terhadap Starbucks yang diketahui mendukung LGBT,berarti umat Islam turut berperan dalam mendukung LGBT.Tujuan penelitian ini adalah untuk mengetahui loyalitas konsumen muslim kepada Starbucks setelah Starbucks mendukung LGBT dan juga untuk mengetahui tanggapan konsumen muslim kepada Starbucks atas pemberian dukungan Starbucks Coffee pada komunitas LGBT..Penelitian ini dilakukan dengan menggunakan metode kualitatif.Dalam penelitian ini penulis menemukan bahwa dukungan Starbucks terhadap LGBT merupakan tindakan yang melanggar etika bisnis dalam lingkup tanggung jawab sosial.terlebih lagi LGBT merupakan perbuatan yang diharamkan dalam Islam.Sehingga dukungan Starbucks terhadap LGBT tidak mendapat respon positif dari kalangan konsumen muslim.Dari
\end{abstract}


2 AT-TAWASSUTH: Jurnal Ekonomi Islam, Volume V No. 1

Januari - Juni 2020: 1 - 21

informan yang dimintai keterangan tidak ada 1 informan pun yang setuju atas dukungan Starbucks Coffee terhadap LGBT.3 dari 5 informan menjadi hilang loyalitasnya kepada Starbucks dan enggan untuk kembali mengunjungi Starbucks. Kata Kunci: Loyalitas,Konsumen Muslim,Starbucks Coffee,Dukungan dan LGBT

\section{Pendahuluan}

Loyalitas pelanggan merupakan hal yang sangat penting untuk diperhatikan dan menjadi impian bagi setiap perusahaan. Setiap perusahaan tentunya sangat mengharapkan akan dapat mempertahankan pelanggannya dalam waktu yang lama. Sebab apabila perusahaan memiliki seorang pelanggan yang loyal, maka hal itu dapat menjadi aset yang sangat bernilai bagi perusahaan. Pelanggan tersebut tidak hanya secara rutin menggunakan produk atau jasa perusahaan, tetapi dengan sendirinya pelanggan tersebut juga akan merekomendasikannya kepada orang lain sesuai dengan pengalaman yang dirasakannya. Dengan kata lain, Pelanggan yang loyal juga dapat secara tidak langsung membantu perusahaan untuk mempromosikan produk atau jasa kepada orang-orang terdekatnya. Tentu saja hal ini akan sangat membantu perusahaan untuk mendapatkan pelanggan baru. Selain itu, Pelanggan yang loyal juga mempunyai kecenderungan lebih rendah untuk berpindah kepada produk atau jasa pesaing. Untuk mendapatkan loyalitas dari para pelanggan, tentu saja akan terwujud apabila pemasar mengetahui kebutuhan dan hal apa yang diinginkan oleh pelanggan sehingga ia dapat mengambil langkah yang tepat untuk mendapatkan loyalitas dari para pelanggannya.

Untuk mendapatkan loyalitas dari para pelanngan, selain menentukan produk yang diinginkan, kualitas dan pelayanan atas produk maupun jasa yang ditawarkan. Tentunya pada era seperti sekarang ini perusahaan juga harus berupaya untuk melakukan pembentukan dan penjagaan citra di mata para pelanggannya. Disinilah setiap perusahaan berupaya untuk unggul dengan pembentukan citra yang ramah lingkungan dan memiliki kepekaan sosial yang dapat dilakukan dengan membuat program tanggung jawab sosial perusahaan/corporate social responsibility yang tepat dan dapat diterima oleh setiap lapisan masyarakat. Keuntungan lain dari program tanggung jawab sosial perusahaan/corporate social responsibility yang tepat, perusahaan dapat menciptakan iklim usaha yang aman dan harmonis, membuat perusahaan dapat menjalankan bisnisnya secara nyaman tanpa adanya penolakan dari program tanggung jawab sosial perusahaan/corporate social responsibility yang dilakukan. 
Dalam Kamus Besar Bahasa Indonesia, Loyalitas diartikan sebagai kepatuhan atau kesetiaan. ${ }^{1}$ Sedangkan Engel mengartikan loyalitas sebagai komitmen mendalam untuk membeli ulang atau mengulang pola prefensi produk atau layanan di masa yang akan datang, yang menyebabkan pembelian berulang merek yang sama atau suatu set merek yang sama, walaupun ada keterlibatan faktor situasional dan upaya-upaya pemasaran yang berpotensi menyebabkan perilaku berpindah merek. ${ }^{2}$ Kemudian Kotler menambahkan bahwasanya kepuasan pelanggan akan terjadi apabila produk yang dipilih melebihi harapan pelanggan atau setidaknya sesuai dengan keinginan pelanggan. Sedangkan ketidakpuasan akan terjadi apabila produk yang dipilih tidak memenuhi harapan yang diinginkan pelanggan. ${ }^{3}$ Sedangkan dalam Islam, loyalitas disebut dengan istilah Al-Wala. Kata Wala berasal dari walayah yang berarti nasab, dukungan, dan pemerdekaan budak. Menurut Syaikhul Islam Ibnu Taimiyah akar dari walayah adalah cinta dan kedekatan. Menurut Syaikh Al-Allamah Abdur-Razaq Afifi berpendapat bahwa Wala merupakan sebagian dari manifestasi ketulusan cinta kepada Allah, kemudian kepada para nabi-Nya dan orang-orang beriman. ${ }^{4}$

Sebagai pemeluk agama Islam sudah seharusnya umat Islam di Indonesia bijak ketika menjadi konsumen, jangan sampai umat Islam di Indonesia loyal terhadap perusahaan jasa yang tidak mendukung nilai-nilai syariat Islam. Ironisnya, tidak sedikit perusahaan-perusahaan yang kurang memperhatikan nilainilai syariat Islam sebagai salah satu bentuk tanggung jawab sosial perusahaan/corporate social responsibility. Sepertihalnya Starbucks yang telah melakukan salah satu bentuk tanggung jawab sosial perusahaan/corporate social responsibility berupa pemberian dukungan terhadap LGBT. Dengan dilakukannya kegiatan tanggung jawab sosial perusahaan /corporate social responsibility berupa pemberian dukungan terhadap LGBT tersebut, dikhawatirkan akan mencederai nilai loyalitas konsumen khususnya umat Islam terhadap Starbucks karena sudah jelas dalam syariat Islam bahwasanya LGBT merupakan tindakan/perbuatan yang diharamkan.

Berdasarkan paparan di atas, dapat dipahami bahwasanya terdapat sesuatu yang mengganjal khususnya bagi diri penulis, di mana salah satu perusahaan yang mendukung komunitas LGBT dan telah melakukan kampanye dengan menyatakan akan menyisihkan sekitar US\$10-20 sen dari setiap pembelian 
Starbucks untuk mendukung pernikahan sejenis, ramai dan memiliki pelanggan yang banyak di negara yang bermayoritaskan agama Islam yaitu Indonesia. Sehingga, penulis merasa tertarik untuk melakukan suatu penelitian yang diberi judul “Analisis Loyalitas Konsumen Muslim Terhadap Starbucks Coffee Pasca Dukungan Starbucks Coffee TerhadapLGBT"

\section{Kajian Teoritis}

\section{Loyalitas}

Dalam Kamus Besar Bahasa Indonesia, Loyalitas diartikan sebagai kepatuhan atau kesetiaan. ${ }^{5}$ Sedangkan Engel mengartikan loyalitas sebagai komitmen mendalam untuk membeli ulang atau mengulang pola prefensi produk atau layanan di masa yang akan datang, yang menyebabkan pembelian berulang merek yang sama atau suatu set merek yang sama, walaupun ada keterlibatan faktor situasional dan upaya-upaya pemasaran yang berpotensi menyebabkan perilaku berpindah merek. ${ }^{6}$ Kemudian Kotler menambahkan bahwasanya kepuasan pelanggan akan terjadi apabila produk yang dipilih melebihi harapan pelanggan atau setidaknya sesuai dengan keinginan pelanggan. Sedangkan ketidakpuasan akan terjadi apabila produk yang dipilih tidak memenuhi harapan yang diinginkan pelanggan. ${ }^{7}$ Sedangkan dalam Islam, loyalitas disebut dengan istilah Al-Wala. Kata Wala berasal dari walayah yang berarti nasab, dukungan, dan pemerdekaan budak. Menurut Syaikhul Islam Ibnu Taimiyah akar dari walayah adalah cinta dan kedekatan. Menurut Syaikh Al-Allamah Abdur-Razaq Afifi berpendapat bahwa Wala merupakan sebagian dari manifestasi ketulusan cinta kepada Allah, kemudian kepada para nabi-Nya dan orang-orang beriman. ${ }^{8}$

Berdasarkan beberapa definisi dan penjelasan mengenai loyalitas tersebut di atas, dapat dipahami bahwasanya loyalitas pelanggan merupakan salah satu bagian penting bagi perusahaan agar perusahaan tersebut dapat menjalankan bisnisnya dengan lancar karena berkaitan dengan kesetiaan para pelanggan dalam jangka waktu yang panjang. Sehingga, perusahaan perlu memperhatikan nilainilai yang dapat mempengaruhi pelanggan agar memiliki loyalitas yang tinggi kepada perusahaan baik terkait produk, pelayanan atau hal-hal lainnya agar pelanggan memutuskan untuk melakukan kembali pembelian dan menghindari pelanggan untuk berhenti menggunakan produk perusahaan. 
Ada beberapa tahap untuk menjadikan calon pembeli menjadi pelanggan yang loyal, menurut Jill Griffin adalah:

1. Melakukan pembelian ulang secara teratur

Pelanggan membeli kembali produk yang sama yang ditawarkan oleh perusahaan.

2. Melakukan pembelian antarlini produk jasa

Pelanggan melakukan pembelian antarlini produk/jasa yang ditawarkan oleh perusahaan.

3. Mereferensikan kepada orang lain

Pelanggan melakukan komunikasi dari mulut ke mulut berkenaan dengan produk tersebut terhadap orang lain.

4. Menunjukkan kekebalan terhadap tarikan pesaing

Pelanggan tidak tertarik terhadap tawaran produk sejenis yang dihasilkan oleh pesaing. ${ }^{9}$

Selain tahap-tahap menjadikan calon pembeli menjadi pelanggan yang loyal sebagaimana tersebut di atas, Fandy Tjiptono juga menyatakan bahwa pelanggan yang benar-benar loyal bukan saja sangat potensial menjadi word of mouth advertisers, namun juga kemungkinan besar loyal pada portofolio produk dan jasa perusahaan untuk jangka waktu yang lama. Perilaku pembelian ulang seringkali di hubungkan dengan loyalitas merek (brand loyalty). Akan tetapi, ada perbedaan di antara keduanya. Loyalitas merek mencerminkan identitas terhadap merek tertentu, sedangkan perilaku pembelian ulang semata-mata menyangkut pembelian merek tertentu yang sama secara berulang kali (bisa jadi satu-satunya merek yang tersedia, merek termurah, dan sebagainya). ${ }^{10}$

Menurut Fandy Tjiptono, loyalitas dibagi dua komponen yaitu loyalitas sebagi perilaku dan loyalitas sebagai sikap. Kombinasi kedua komponen tersebut menghasilkan empat situasi kemungkinan loyalitas yaitu:

1. No Loyalty

Bila sikap dan perilaku pembelian ulang pelanggan sama-sama lemah, maka loyalitas tidak terbentuk. Ada dua kemungkinan penyebabnya, yang pertama sikap yang lemah (mendekati netral) dapat terjadi bila suatu produk atau jasa baru diperkenalkan atau pemasarnya tidak mampu mengkonsumsikan keunggulan unik produknya. Penyebab yang kedua berkaitan dengan 
6 AT-TAWASSUTH: Jurnal Ekonomi Islam, Volume V No. 1

Januari - Juni 2020: 1 - 21

dinamika pasar, dimana merek-merek yang berkompetisi dipersepsikan serupa atau sama. Konsekuensinya, pemasar mungkin sangat sulit membentuk sikap yang positif atau kuat terhadap produk atau perusahaannya.

2. Spurious loyalty

Situasi semacam ini ditandai dengan pengaruh faktor non sikap terhadap perilaku, misalnya norma subjektif dan faktor situasional. Situasi ini terjadi dimana konsumen sulit membedakan berbagai merek dalam kategori produk dengan keterlibatan rendah, sehingga pembelian ulang dilakukan atas dasar pertimbangan situasional. Dalam konteks produk industrial, pengaruh sosial juga dapat menimbulkan spurious loyalty. Jika disertai penyempurnaan kualitas produk dan komunikasi pemasaran, ikatan sosial semacam itu dapat memperkokoh loyalitas pelanggan.

3. Latent loyalty

Situasi latent loyalty tercermin bila sikap yang kuat di sertai pola pembelian ulang yang lemah. Situasi yang menjadi perhatian besar para pemasar ini di sebabkan pengaruh faktor-faktor non sikap yang sama kuat atau bahkan cenderung lebih kuat daripada faktor sikap dalam menentukan pembelian ulang.

4. Loyalty

Situasi ini merupakan situasi ideal yang paling diharapkan para pemasar, di mana konsumen bersikap positif terhadap produk atau produsen (penyedia jasa) dan disertai pola pembelian ulang yang konsisten. ${ }^{11}$

Kemudian, Ratih menjelaskan beberapa karakteristik pelanggan yang memiliki loyalitas, diantaranya:

1. Melakukan pembelian secara teratur.

2. Pelanggan senantiasa membeli produk secara teratur atau berkesinambungan yang ditawarkan oleh pihak perusahaan.

3. Mereferensikan produk perusahaan kepada orang lain.

4. Pelanggan yang memiliki loyalitas senantiasa merekomendasikan kepada orang lain tentang produk perusahaan yang telah digunakan oleh pelanggan sehinggan menjadi sarana pemasaran tersendiri bagi perusahaan.

5. Menunjukkan kekebalan dari daya tarik produk sejenis dari pesaing. 
Pelanggan merasa atau berkomitmen untuk tetap menggunakan produk perusahaan tersebut yang di tawarkan oleh perusahaan atau akan selalu tertarik pada produk-produk yang perusahaan tersebut tawarkan. ${ }^{12}$

Dalam agama Islam, Nabi Ibrahim as. telah menjadi teladan yang baik (uswah hasanah) dalam berwala kepada Tuhannya, agamanya, dan hamba-hamba Allah yang beriman. Sejarah hidup Nabi Ibrahim dengan kaumnya dengan sesuatu yang baik, yaitu kepada penyembahan dan pengesaan Allah, mengkhususkan ibadah kepada-Nya serta kufur terhadap setiap taghut yang diibadahi selain Allah. Contoh tentang bentuk wala ${ }^{e e}$ ini juga dapat diperoleh dari kisah seorang sahabat agung, Abdullah bin Quhafah As-Sahmi, dan sikapnya terhadap Raja Romawi. Raja membujuknya, hingga akan membagi kekuasaannya, namun ia tetap menolak. Raja mengancamnya akan membunuh dan membakarnya, namun ia tetap tidak mau masuk ke agama Nasrani. Itu semua merupakan bukti yang jelas dan dalil yang sebenarnya tentang dalamnya loyalitas dan menancapnya akidah ini di dalam jiwa-jiwa yang agung itu. ${ }^{13}$

Dari beberapa contoh kisah di atas menggambarkan betapa pentingnya sebuah loyalitas dalam Islam sehingga sikap loyal sangat diperlukan dalam agama, begitupun ketika bekerja di dalam sebuah perusahaan. Salah satu bentuk dari sikap loyal ini adalah taat/patuh kepada aturan. Allah memerintahkan untuk senantiasa patuh terhadap aturan yang berlaku.

\section{Perilaku Konsumen}

Menurut Mangkunegara perilaku konsumen merupakan suatu tindakantindakan yang dilakukan oleh individu, kelompok atau organisasi yang berhubungan dengan proses pengambilan keputusan dalam mendapatkan, dan menggunakan barang-barang atau jasa ekonomi yang dapat dipengaruhi oleh lingkungan. ${ }^{14}$ Kemudian menurut Kotler dan Keller Perilaku konsumen adalah studi tentang bagaimana individu, kelompok, dan organisasi memilih, membeli, menggunakan, dan bagaimana barang, jasa, ide, atau pengalaman untuk memuaskan kebutuhan dan keinginan mereka. ${ }^{15}$ Sedangkan menurut Peter J. Paul dan Jerry C Olson menyatakan bahwa perilaku konsumen merupakan interaksi dinamis antara pengaruh dan kondisi perilaku dan kejadian di sekitar lingkungan dimana manusia melakukan aspek pertukaran dalam kehidupan mereka. ${ }^{16}$ 
Januari - Juni 2020: 1 - 21

Berdasarkan beberapa definisi prilaku konsumen tersebut diatas, dapat dipahami bahwasanya prilaku konsumen merupakan proses pengambilan keputusan yang melibatkan konsumen dalam menilai, mendapatkan dan mempergunakan barangbarang dan jasa.

Menurut Philip Kotler perilaku konsumen dipengaruhi oleh beberapa faktor diantaranya:

1. Faktor budaya

Faktor budaya merupakan hal yang sangat penting dalam perilaku pembelian yang mana faktor budaya ini terdiri dari budaya dan kelas sosial. Budaya merupakan penentu keinginan dan perilaku yang paling dasar. Kelas sosial adalah pembagian dalam masyarakat yang relatif homogen dan permanen, yang tersusun secara hirarkis dan yang para anggotanya menganut nilai, minat, dan perilaku yang serupa.

2. Faktor Sosial

Faktor sosial dipengaruhi oleh: kelompok acuan, keluarga, dan status sosial: ${ }^{17}$

a. Kelompok acuan: seseorang terdiri dari semua kelompok yeng memiliki pengaruh langsung atau tidak langsung terhadap sikap atau perilaku seseorang tersebut

b. Keluarga: merupakan organisasi pembelian konsumen yang paling penting dalam masyarakat, dan anggota para keluarga menjadi kelompok acuan primer yang paling berpengaruh

c. Peran dan tatus sosial: peran meliputi kegiatan yang diharapkan akan dilakukan oleh seseorang, masing-masing peran menghasilkan status. ${ }^{18}$

3. Faktor Pribadi

Karakteristik tersebut meliputi:

a. Usia dan tahap siklus hidup: orang membeli barang dan jasa berbedabeda sepanjang hidupnya.

b. Pekerjaan dan lingkungan ekonomi

c. Gaya hidup: pola hidup seseorang di dunia yang terungkap pada aktivitas, minat dan opininya.

d. Kepribadian dan konsep diri. Kepribadian adalah ciri bawaan psikologi manusia yang terbedakan yang manghasilkan tanggapan yang relatif konsisten dan bertahan lama terhadap rangsangan lingkungannya. 
Konsep diri ada 3 yaitu konsep diri aktual (memandang dirinya seperti apa), konsep diri ideal (memandang dirinya ingin seperti apa), konsep diri orang lain (manganggap orang lain memandang dirinya seperti apa). ${ }^{19}$

\section{Faktor Psikologis}

Pilihan membeli seserang dipengaruhi oleh empat faktor psikologis utama yaitu:

a. Motivasi

Motivasi muncul karena adanya kebutuhan yang dirasakan oleh konsumen.

Kebutuhan sndiri muncul karena konsumen merasakan ketidaknyamanan antara yang seharusnya dirasakan dan yang sesungguhnya diasakan. Kebuuhan yang dirasakan tersebut mendorong seseorang untuk melakukan tindakan untuk memenuhi kebutuhan tersebut. Artinya, motivasi adalah daya dorong yang muncul dari seorang konsumen yang akan mempengaruhi proses keputusan konsumen dalam membeli dan menggunakan barang dan jasa

b. Persepsi Konsumen

Persepsi konsumen adalah proses dimana kita memilih, mengatur, dan menerjemahkan masukan informasi untuk menciptakan gambaran dunia yang berarti. Poin utamanya adalah bahwa persepsi tidak hanya tergantung pada rangsangan fisik, tetapi juga pada hubungan rangsangan terhadap bidang yang mengelilinginya.

c. Sikap Konsumen

Sikap konsumen adalah faktor penting yang akan mempengaruhi keputusan konsumen. Konsep sikap sangat terkait dengan konsep kepercayaan dan perilaku. Sikap merupakan ungkapan perasaan konsumen tentang suatu objek apakah disukai atau tidak, dan sikap juga menggambarkan kepercayaan konsumen terhadap berbagai atribut dan manfaat dari objek tersebut. ${ }^{20}$

\section{Lesbian,Gay,Biseksual,dan Transgender}

Lesbian berasal dari kata Lesbos yaitu pulau di tengah lautan Egis yang pada zaman kuno dihuni oleh para wanita. Menurut mitologi Yunani, hubungan percintaan sejenis terjadi di pulau itu antara putri Shappo dan Athis. ${ }^{21}$ Sedangkan 
menurut Kamus Besar Bahasa Indonesia, arti dari kata Lesbian yaitu pasangan perempuan dengan perempuan, wanita yang mencintai atau merasakan rangsangan seksual sesama jenisnya, atau disebut sebagai wanita homoseks. ${ }^{22}$ Berdasarkan pengertian tersebut, dapat dipahami bahwasanya lesbian adalah suatu hubungan yang tidak normal dimana wanita mencintai sesama jenis (wanita) yang berujung pada adanya hubungan seksual sesama jenis. Kemudian, jika ditinjau dari jenis atau kelompoknya, kaum wanita terdiri dari dua kelompok homoseksualitas, yaitu: kelompok pertama ialah wanita yang menujukkan banyak ciri-ciri kelakilakian, baik dalam susunan jasmani dan tingkah lakunya, maupun pada pemilihan objek erotiknya. Kelompok yang kedua ialah mereka yang tidak memiliki tandatanda kelainan fisik. ${ }^{23}$

Sedangkan gay atau homoseksual adalah laki-laki yang menyalurkan kebutuhan seksualnya pada sesama jenis lelaki. ${ }^{24}$ Kemudian, Yahya Ma'hsum dan Roellya Arrdhyaninq Tyas mengemukakan, sebenarnya antara gay dan waria tidak memiliki perbedaan orientasi seksual. Mereka tertarik antara sesama jenis, hanya saja ada beberapa hal yang membuat keduanya berbeda satu sama lain, dimana Penampilan gay secara fisik sama dengan pria, secara psikologis dia mengidentifikasi dirinya sebagai pria. ${ }^{25}$ Berdasarkan penjelasan tersebut, dapat dipahami bahwasanya lesbian merupakan penyimpangan sex yang dilakukan atau berorientasi pada sesama wanita, sedangkan gay penyimpangan sex yang dilakukan atau berorientasi oleh sesama pria.

Orientasi seksual menurut Musdah Mulia, adalah kapasitas yang dimiliki setiap manusia berkaitan dengan ketertarikan emosi, rasa sayang, dan hubungan seksual. Disebut hetero jika orientasi seksualnya tertuju pada lain jenis kelamin. Berikutnya, dinamai homo jika orientasi seksualnya sesama jenis kelamin; sesama laki-laki dinamakan gay, sesama perempuan disebut lesbian,dan sesama waria. Biseksual, jika orientasi seksualnya ganda, yaitu seseorang yang tertarik pada sesama jenis sekaligus juga pada lawan jenis. Sebaliknya,aseksual tidak tertarik pada keduanya, baik sesama maupun lawan jenis. ${ }^{26}$

Sedangakan transgender atau Transeksual menurut Heuken, sebagaimana dikutip oleh Koeswinarno, adalah seseorang yang jenis kelaminnya secara jasmani sempurna dan jelas, tetapi secara psikis cenderung untuk menampilkan diri sebagai lawan jenis. ${ }^{27}$ Sedangkan Marzuki mendefinisikan transeksual sebagai 
gejala ketidakpuasan seseorang pada jenis kelamin yang dimilikinya karena merasa memiliki seksualitas yang berlawanan. ${ }^{28}$ Davidson dan Neale dalam penelitiannya tentang transeksualisme, sebagaimana yang di kutip oleh Koeswinarno, menyimpulkan bahwa salah satu penyebab perilaku transeksualisme adalah heterophobia, yaitu ada ketakutan pada hubungan seks lawan jenis atau antar jenis kelamin karena pengalaman yang salah. ${ }^{29}$

Kemudian transgender dikenal sebagai bentuk paling ekstrim dari pengubahan atau pertukaran gender. Hal ini disebabkan karena keinginan mereka tidak hanya sebatas berpakaian, berdandan dan bertingkahlaku sebagaimana perempuan, tetapi juga mengganti alat kelamin mereka melalui operasi agar sesuai dengan kepribadian atau jiwa yang mereka miliki. Seorang transeksual yang telah memulai proses hormonal dan operasi pengubahan kelamin namun gagal disebut transeksual parsial. ${ }^{30}$ Berbeda dengan transvestit,cross dressing (berpakaian silang kelamin) yang dilakukan oleh kaum transeksual tidak bertujuan untuk memenuhi kebutuhan seksual tetapi untuk mendandani tubuh mereka agar sesuai dengan kepribadian yang mereka miliki. Dan hal ini merupakan satu hal yang paling penting untuk membedakan transeksual dengan yang lainnya terutama dengan penderita transvestisme. Sehingga pada kaum transeksual yang terganggu adalah identitas kelaminnya (identitas gender) yang bertolak belakang dengan psikenya. Pada umumnya kaum waria menganggap bahwa transeksual berbeda dengan waria. Namun semua ahli sepakat bahwa waria termasuk dalam kelainan seksual yang disebut dengan transeksualisme yaitu suatu gejala seseorang merasa memiliki seksualitas yang berlawanan dengan struktur fisiknya. ${ }^{31}$

Sedangkan Biseksual merupakan ketertarikan romantis, ketertarikan seksual, atau kebiasaan seksual kepada pria maupun wanita. Istilah ini digunakan untuk menggambarkan bentuk kehidupan manusia yang memiliki kecendrungan seksual sesama jenis dan ke lain jenis sekaligus, atau bisa disebut dengan istilah panseksualitas. $^{32}$ Dengan kata lain, Biseksual ini merupakan bagian dari homosexual. Hanya saja, jika pada homoseksual di lakukan berdasarkan kesukaan pada sesama jenis, sedangkan biseksual merupakan penyaluran hasrat biologis yang dilakukan tidak hanya pada sesama jenis melainkan juga kelain jenis sekaligus. Konteks trangender/transeksual merupakan salah satu wujud dimana terdapat beberapa bagian manusia yang hendak lari kenyataan dari jenis kelamin 
yang dimiliki. ${ }^{33}$ Kalaupun dalam kenyataan hidup ini ada sesuatu yang kurang sempurna merupakan hal yang wajar, namun bukan berarti lari ketidaksempurnaan itu. Tika mengatakan perilaku LGBT lebih banyak terjadi karena salah bergaul dan kebiasaan daripada masalah hormon. ${ }^{34} \mathrm{Hal}$ ini juga sependapat dengan Edi Purwanta yang mengatakan perilaku dapat dikurangi atau dihilangkan, bahkan perilaku yang baru terbentuk pun dapat dikurangi atau juga dihilangkan. ${ }^{35}$

\section{Metode Penelitian}

Penelitian ini menggunakan Metode Kualitatif dengan pendekatan Studi Kasus untuk mendapatkan berbagai informasi yang dibutuhkan. Bogdan dan Taylor mendifinisikan metodologi kualitatif sebagai prosedur penelitian yang menghasilkan data deskriptif berupa kata-kata tertulis atau lisan dari orang-orang dan perilaku yang dapat diamati. ${ }^{36}$ Kemudian alasan pendekatan penelitian ini di pilih oleh penulis menggunakan pendekatan studi kasus, karena peneliti merasa kegiatan ataupun komunitas LGBT merupakan suatu permasalahan khususnya bagi umat Islam sebagaimana yang sudah diterangkan dalam Alquran dan Hadis yang sudah jelas-jelas melarang perbuatan-perbuatan tersebut. Sehingga diharapkan penelitian ini dapat mengungkap suatu pemahaman baru mengenai loyalitas konsumen muslim Starbucks yang telah diketahui bahwa Starbucks mendukung kegiatan LGBT. Adapun yang di maksud dengan studi kasus sebagaimana Yin menyatakan bahwa studi kasus adalah suatu inquiry empiris yang mendalami fenomena dalam konteks kehidupan nyata, ketika batas antara fenomena dan konteks tak tampak secara tegas. ${ }^{37}$

\section{Hasil Penelitian dan Pembahasan}

\section{Tanggapan Konsumen Muslim Kepada Starbucks Coffee Setelah Starbucks}

\section{Coffee Mendukung LGBT}

Informan 1 pada dasarnya mengetahui betul mengenai LGBT, dan menerangkan mengenai dampak buruk LGBT, sebagaimana dalam wawancara informan 1 menyatakan "........ya nggak bagus.. mmm..dampak buruknya..bisa ngerusak..ini aja..ngerusak..generasi kita juga". Jika ditinjau lebih dalam informan 1 mengaitkan dampak buruk LGBT dalam kategori sosial sebagaimana dalam suatu Penelitian ditemukan bahwasanya seorang gay mempunyai pasangan 
antara 20-106 orang per tahunnya. Sedangkan pasangan zina seseorang tidak lebih dari 8 orang seumur hidupnya $43 \%$ dari golongan kaum gay yang berhasil didata dan diteliti menyatakan bahwasanya selama hidupnya mereka melakukan homo seksual dengan lebih dari 500 orang. 28\% melakukannya dengan lebih dari 1000 orang. $79 \%$ dari mereka mengatakan bahwa pasangan homonya tersebut berasal dari orang yang tidak dikenalinya sama sekali. $70 \%$ dari mereka hanya merupakan pasangan kencan satu malam atau beberapa menit saja. Hal itu jelas-jelas melanggar nilai-nilai sosial masyarakat. ${ }^{38}$ Atas dasar tersebut, informan 1 sangat tidak mendukung adanya kegiatan LGBT termasuk juga tidak mendukung Starbucks mendukung LGBT. Bahkan informan 1 ini juga telah memboikot Starbucks sebagaimana dalam wawancaranya informan 1 menyatakan "nggak setujulah..bahkan kita..memboikot Starbuck sekarang" Hal ini juga dapat dijadikan sebagai salah satu bukti bahwasanya informan 1 telah melakukan amar ma'ruf nahi munkar pada tingkatan pertama yaitu mencegah dengan tangannya (keputusan konsumen untuk tidak mengunjungi/mengkonsumsi Starbucks)

Begitupun informan 2, informan 2 juga pada dasarnya mengetahui tentang LGBT dan disangkut pautkan dengan ajaran agama Islam yang mengharamkan LGBT tersebut. Selain itu, informan 2 juga menyatakan berbagai dampak buruk yang diakibatkan dari perbuatan LGBT, sebagaimana dalam wawancara, informan 2 menyatakan " $\mathrm{hmm}$.. penyakit sih itu jadi penyimpangan sex... yah bisa merusak generasi penerus bangsa sih.." atas dasar tersebut, informan 2 sama halnya dengan informan 1 yang tidak mendukung LGBT dan juga tidak menyetujui Starbucks mendukung LGBT karena informan 2 menyatakan bahwasanya LGBT merupakan perbuatan yang diharamkan dan merupakan suatu penyakit yang bisa merusak generasi penerus bangsa.

Informan 2 yang juga aktif dalam kegiatan keagamaan dan juga sering memperhatikan isu-isu agama tampaknya tidak begitu memperhatikan tempattempat ataupun perusahaan yang mendukung penyimpangan syariat Islam. Hal ini tercermin dalam pernyataan yang disampaikan oleh informan 2 yang menyatakan dalam wawancaranya:

“.... Yah itu sih menurut saya gak bagus yah karena itu memang jelas dilarang dalam agama Islam.. itu memang tempat maksiat yang tidak bolehlah untuk kita-kita dikunjungin karena itu memang jelas itu dalam qur'an haram.... hmmm.. di tutup sih tidak ya.. tapi balik lagi ke 
manusianya.. kalau sepengetahuan dia itu haram... yah jangan dikunjungin khusus orang-orang yang non muslim aja yang kesana gitu..

Begitupun Informan 3, informan 3 mengetahui betul mengenai LGBT, sebagaimana dalam wawancara ketika penulis menanyakan LGBT, informan 3 menjawab: "Aduh.. homo-homo itu teh kesukaan kau itu(merujuk pada teman informan) ..hehehee... tau.. tau... gak beres itu.. kaum luth itu.. Disisi lain, informan 3 juga memberikan berbagai pernyataan mengenai dampak buruk LGBT, sebagaimana dalam wawancara, informan 3 juga menyatakan:

"Sekarang gini bang.. kalau ada LGBT di kita katakan tadi kan di Sumatera Utara kan Medan yah. . hmm.. setiap musibah pernah.. itu kan bisa buat yang.. itu kan virus kalau di bilang dikatakan itu virus itu bisa memancing seperti orang pengikutnya.. kalau kita berkawan sama banci seumpamakan itu bisa jadi banci itu memang real fakta, dari jaman SMA kami dulu memang ada itu kawan yang kayak gitu. Pernah satu orang bencong kita katakanlah banci kan waria waktu itu kita bilang kan.. dan setiap satu sekolah SMA dulu kan itu kan pasti ada yang ngikut,, pasti ada waria.. jadi kalau........ dampak buruknya ada itu pasti ada yang ngikut itu.. di musnahkan itu bang kalau perlu bang daripada kita yang kena nanti kan kita yang orang muslim cakap kita orang muslim gak kita tolong kan kayak gitu kan ya di gempa karena main diatas sini apa nggak hancur kayak kaum Luth awak yang kena kan dia yang berjinah maaf cakapnya sesama jenis awak yang kena mati awak oleh dia.."

Informan 3 juga pada hakikatnya tidak menyetujui Starbucks mendukung LGBT. Bahkan informan 3 juga menganggap sebaiknya Starbucks ditutup saja kalau memumngkinkan, sebagaimana dalam wawancara informan 3 menyatakan:

"Kalau itu kan kita kan kalau di bilang kan mayoritas semua agama ada di Sumatera Utara ini kan masuk Medan juga.. jadi kalau untuk di tutup itu berarti kita buka syariat Islam kan, ya kalau memang bisa yah kenapa nggak kan gitu.. kita tutup kayak diskotik kalau bisa kenapa nggak.. lebih bagus kan.. ya kalau memang gak bisa juga ya berarti kita harus gimana lagi memang dari jaman apa Soekarno dulu ya kan gitu seperti itulah kalau pandangan saya kalau dibuka lebih bagus lagi.. ikh di buka,, di tutup sory sory di tutup kok di buka aduhh.."

Kemudian samahalnya dengan informan-informan sebelumnya, informan 4 juga mengetahui tentang LGBT dan di kaitkan dengan syariat Islam yang telah mengharamkan LGBT. Bahkan, informan 3 juga memberikan pernyataanpernyataan mengenai dampak buruk dari LGBT tersebut. sebagaimana dalam wawancara informan 4 menyatakan: " hmmm... merusak moral anak-anak muda, 
virus HIV, apalagi yah.. itu aja sih intinya". Atas dasar tersebut, informan 4juga tidak mendukung LGBT dan tidak menyetujui Starbucks mendukung LGBT bahkan informan 3 ini menyatakan Starbucks lebih baik di tutup saja, sebagaimana dalam pernyataannya dalam wawancara, informan 4 menyatakan: hmmm, kalau bisa di tutup aja gitu..

Sama halnya dengan informan 1,2,3, dan 4 informan 5 juga mengetahui LGBT, sebagaimana dalam wawancara, informan 5 menyatakan: "Tendensi negatif lah bang..LGBT itu... mmm..sebenarnya LGBT itu kan bisa di bilang dia melawan kodrat bang...jadi kalau dampak buruknya udah pasti..ngerusak lingkungan lah bang.karena.artinya..manusia itu dah berjaalan di luar kodrat yang diciptakan.kan gitu..gitu dia bang.." atas dasar tersebut, informan 5 juga sama halnya dengan informan-informan sebelumnya, informan 5 juga tidak mendukung kegiatan LGBT.

Selanjutnya, terkait dengan dukungan Starbucks terhadap LGBT, informan 5 ini bersikap netral, sebagaimana dalam wawancaranya, informan 5 menyatakan: " mmm..kalau secara personal sih nggak bang karena saya pribadi kan nolak LGBT..tapi kalau misalnya..dibilang setuju apa nggak ya..nggak ada ini sih..nggak ada pendapat untuk mereka gitu..kan hak mereka untuk mendukung apa nggakkan gitu..".

Dari hasil wawancara yang dilakukan semua informan tidak setuju dengan gerakan Starbucks Coffee yang mendukung LGBT,ini berdampak buruk bagi Starbucks Coffee karena menyebabkan berkurangnya loyalitas konsumen Muslim terhadap Starbucks Coffee. Starbucks Coffee sebaiknya melakukan aksi sosial yang tidak bertolak belakang dengan nilai-nilai Agama.

Pada dasarnya perusahaan yang melakukan aksi sosial akan mendapat sambutan hangat dari masyarakat dan akan berdampak positif terhadap perusahaan tersebut, contohnya yang dilakukan PT BNI Syariah Cabang Makassar. Kegiatan CSR yang telah dilaksanakan oleh PT BNI Syariah Cabang Makassar, memberikan dampak terhadap kepercayaan dan loyalitas nasabah pada 81 entitas tersebut. PT BNI Syariah Cabang Makassar, mendapat sambutan hangat di mata masyarakat dengan kegiatan-kegiatan CSR yang telah dilaksanakan. Citra dari entitas tersebut juga mengalami peningkatan dimata masyarakat, sehingga kepercayaan nasabah terhadap PT BNI Syariah Cabang Makassar juga meningkat. 
Januari - Juni 2020: 1 - 21

Dengan adanya kepercayaan tersebut, nasabah menjadi loyal setelah mengetahui adanya kegiatan-kegiatan CSR yang dilaksanakan. Value added-nya adalah CSR yang diimplementasikan sesuai dengan perspektif syariah, yang mengedepankan nilai-nilai ibadah. ${ }^{39}$

Berikut ini adalah Hasil Wawancara Informan Mengenai Loyalitas Informan Terhadap Starbucks Coffee dapat dilihat dalam tabel ini:

Tabel 1 Tabulasi Hasil Wawancara

\begin{tabular}{|c|c|c|c|c|c|}
\hline \multirow{2}{*}{ Pertanyaan } & \multicolumn{5}{|c|}{ Informan } \\
\hline & 1 & 2 & 3 & 4 & 5 \\
\hline $\begin{array}{l}\text { Seberapa } \\
\text { sering } \\
\text { mengunjungi } \\
\text { Starbucks? }\end{array}$ & $\begin{array}{l}\text { Lebih dari } \\
10 \text { kali }\end{array}$ & $\begin{array}{l}\text { Seminggu } \\
\text { dua kali }\end{array}$ & $\begin{array}{l}\text { Seminggu } \\
\text { dua kali }\end{array}$ & $\begin{array}{l}\text { Satu bulan } \\
\text { satu kali }\end{array}$ & $\begin{array}{l}\text { Baru dua } \\
\text { kali }\end{array}$ \\
\hline $\begin{array}{l}\text { Mengapa } \\
\text { sering } \\
\text { mengunjungi } \\
\text { Starbucks? }\end{array}$ & $\begin{array}{l}\text { Ada } \\
\text { pertemuan }\end{array}$ & $\begin{array}{l}\text { Tempatny } \\
\text { a Nyaman }\end{array}$ & Kopinya & $\begin{array}{l}\text { Diajak } \\
\text { teman saja }\end{array}$ & Tempat \\
\hline $\begin{array}{l}\text { Apa yang } \\
\text { paling } \\
\text { disukai dari } \\
\text { Starbucks? }\end{array}$ & $\begin{array}{l}\text { Kualitas } \\
\text { Pelayanan }\end{array}$ & Kopinya & $\begin{array}{l}\text { Kualitas } \\
\text { Pelayanan }\end{array}$ & Tempatnya & Produk \\
\hline $\begin{array}{l}\text { Apakah suka } \\
\text { mengajak } \\
\text { orang lain ke } \\
\text { Starbucks? }\end{array}$ & Tidak & Tidak & Pernah & Tidak & Tidak \\
\hline $\begin{array}{l}\text { Apakah } \\
\text { tertarik } \\
\text { mengunjungi } \\
\text { cafe lain? }\end{array}$ & Tertarik & Tertarik & Tertarik & Tertarik & Tertarik \\
\hline $\begin{array}{l}\text { Apakah } \\
\text { mengetahui } \\
\text { Starbucks } \\
\text { mendukung }\end{array}$ & Tahu & Tahu & Tahu & Tahu & Tahu \\
\hline
\end{tabular}


Muhammad Reza: Analisis Loyalitas Konsumen Muslim |17

\begin{tabular}{|c|c|c|c|c|c|}
\hline LGBT? & & & & & \\
\hline $\begin{array}{l}\text { Sesudah } \\
\text { mendengar } \\
\text { Starbucks } \\
\text { mendukung } \\
\text { LGBT, } \\
\text { bagaimana } \\
\text { intensitas } \\
\text { berkunjung } \\
\text { ke Starbucks? }\end{array}$ & $\begin{array}{l}\text { Tidak } \\
\text { pernah } \\
\text { berkunjun } \\
\text { g lagi }\end{array}$ & Sama saja & $\begin{array}{l}\text { Semakin } \\
\text { Jarang } \\
\text { Berkunjun } \\
\mathrm{g}\end{array}$ & $\begin{array}{l}\text { Tidak } \\
\text { pernah } \\
\text { berkunjung } \\
\text { lagi }\end{array}$ & $\begin{array}{l}\text { Tidak } \\
\text { Mau } \\
\text { berkunju } \\
\text { g lagi }\end{array}$ \\
\hline
\end{tabular}

Sumber: Data diolah, 2019.

\section{Kesimpulan}

Dapat diketahui bahwa dari 5 informan yang dimintai keterangannya tidak ada satupun informan yang setuju atas dukungan Starbuck Coffee terhadap LGBT,bahkan 1 dari 5 informan menginginkan agar Starbucks Coffee di tutup. Dan 3 dari 5 informan menjadi hilang loyalitasnya terhadap Starbucks Coffee pasca dukungan Starbucks Coffe terhadap LGBT,1 informan masih mengunjungi Starbucks Coffee pasca dukungan Starbucks Coffe terhadap LGBT, namun intensitas kunjungannya berkurang,1 informan lainnya masih mengunjungi Starbucks Coffee dan tidak mengurangi intensitas kedatangannya ke Starbucks Coffee pasca dukungan Starbucks Coffee terhadap LGBT.

\section{(Endnote)}

${ }^{1}$ Depdiknas. Kamus Besar Bahasa Indonesia.(Jakarta: Balai Pustaka, 2001), h. 603.

${ }^{2}$ Engel, J.F, Blackwell, Rd dan Miniard, DW. Perilaku Konsumen. Terj. Jilid 1. (Jakarta: Bina Rupa Aksara,1995), h. 144.

${ }^{3}$ Philip Kotler dan Kevin Lane Keller, Manajemen Pemasaran, Edisi Ketiga Belas, Jilid 1 (Jakarta: Erlangga, 2009), h. 139.

${ }^{4}$ Muhammad bin Sa'id Al-Qahthani. Al-Walâ' Wal-Barâ' : Loyalitas \& Antiloyalitas Dalam Islam. (Surakarta: Era Intermedia, 2005), h. 87.

${ }^{5}$ Depdiknas. Kamus Besar Bahasa Indonesia. (Jakarta: Balai Pustaka, 2001), h. 603.

${ }^{6}$ Engel, J.F, Blackwell, Rd dan Miniard, DW. Perilaku Konsumen. Terj. Jilid 1. (Jakarta: Bina Rupa Aksara,1995), h. 144. 
${ }^{7}$ Philip Kotler dan Kevin Lane Keller, Manajemen Pemasaran, Edisi Ketiga Belas, Jilid 1 (Jakarta: Erlangga, 2009), h. 139.

${ }^{8}$ Muhammad bin Sa'id Al-Qahthani. Al-Walâ' Wal-Barâ' : Loyalitas \& Antiloyalitas Dalam Islam. (Surakarta: Era Intermedia, 2005), h. 87.

${ }^{9}$ Jill Griffin, Customer Loyalty Menumbuhkan dan Mempertahankan Kesetiaan Pelanggan, Alih Bahasa Dwi Kartini Yahya (Jakarta: Erlangga, 2005), h. 31.

${ }^{10}$ Fandy Tjiptono, Pemasaran Jasa (Malang : Bayu Media, 2006), h. 107.

${ }^{11}$ Ibid., h. 110

12 Ratih, Hurriyati, Bauran Pemasaran dan Loyalitas Konsumen. (Bandung: Alfhabeta, 2010), h. 130 .

${ }^{13}$ Muhammad bin Sa'id Al-Qahthani. Al-Walâ' Wal-Barâ' : Loyalitas \& Antiloyalitas Dalam Islam. (Surakarta: Era Intermedia, 2005), h.152-153.

14 Mangkunegara, A.P, Perilaku Konsumen, Edisi Revisi, Cetakan Keempat, (Bandung: Refika Aditama, 2009), h.4.

15 Philip Kotler dan Kevin Lane Keller, Manajemen Pemasaran, Edisi 13 Jilid 1, Alih Bahasa, Bob Sabran, (Erlangga: Jakarta, 2008), h.166.

${ }^{16}$ Peter J. Paul Dan Olson, Perilaku Konsumen dan Strategi Pemasaran, Edisi ke Empat, Jilid I, (Jakarta: Erlangga, 2006), h. 6.

${ }^{17}$ Philip Kottler, Manajemen Pemasaran, (Jakarta: IKAPI, 2000), h.187

${ }^{18}$ Ibid, h.183.

${ }^{19}$ Ibid., h. 191

${ }^{20}$ Ibid., h. 196-200

${ }^{21}$ Kartini Kartono, Psikologi Abnormal dan Abnormalitas Seksual, (Bandung: Mandar Maju, 1989), h. 248.

22 Juwilda. Transgender: Manusia Keragaman dan Kesetaraannya. (Bandung: Universitas Sriwijaya, 2010), h. 3.

${ }^{23}$ Ibid., h. 265.

${ }^{24}$ Burhnai MS, Kamus Ilmiah Populer, (Jombang: Lintas Media, 2000), h.193, h. 349.

25 Yahya Maehsum dan Roellya Arrdhyaninq Tyas, Bedanya Homoseksual dengan Waria, (Jakarta: 2004).

${ }^{26}$ Siti Musdah Mulia, Islam dan Homoseksualitas; Membaca Ulang Pemahaman Islam, dalam Jurnal Gandrung, Vol.1, No.1, Juni 2010, h.13-14. 54

${ }^{27}$ Koeswinarno, Hidup Sebagai Waria, (Yogyakarta: PT LKiS Pelangi Aksara, 2004), hlm. 
${ }^{28}$ Marzuki Umar Sa'abah, Perilaku Seks Menyimpang dan Seksualitas Kontemporer Umat Islam, (Jogjakarta : UII Press,2001), h. 145.

${ }^{29}$ Koeswinarno, Pengaruh Ruang Sosial terhadap Waria serta Tinjauan Islam terhadapnya, Jurnal Penelitian Agama, Vol. XI, No. 2 Mei-Agustus 2002, (Yogyakarta : Pusat Penelitian IAIN Sunan Kalijaga, 2002), h.218.

30 Yash,Transseksualisme: Sebuah Studi Kasus Perkembangan Transeksual Perempuan Ke Laki-Laki, (Semarang: AINI, 2003), h.33

${ }^{31}$ Jeffrey S Nevid, Psikologi Abnormal, (Jakarta: Penerbit Erlangga, 2003), h.266

${ }^{32}$ Burhnai MS, Kamus Ilmiah Populer, (Jombang: Lintas Media, 2000), h,65.

${ }^{33}$ Zunli Nadia, Waria Laknat atau Kodrat, (Yogyakarta: Pustaka Marwa, 2005), h,78 2016).

${ }^{34}$ Tika Bisono, "LGBT Masih Dapat Disembuhkan”, terbit dalam Republika 15 Februari,

35 Edi Purwanta, Modifikasi Perilaku Alternatif Penanganan Anak Berkebutuhan Khusus (Yogyakarta: Pustaka Pelajar, 2012), h. 67 - 68. 3.

${ }^{36}$ Lexy J. Moleong, Metode Penelitian Kualitatif, (Bandung: Remaja. Rosdakarya, 1994), h. 64.

${ }^{37}$ Burhan Bungin, Metodologi Penelitian Kualitatif. (Jakarta: Prenada Media Group, 2005) h.

38 El-Qudah, Abdul Hamid. Kaum Luth Masa Kini, (Jakarta: Yayasan Islah Bina Umat, 2015), hal. 68 .

39 Pri Ramadhani H.US Rikanita,'Implementasi Corporate Social Responsibility Terhadap Kepercayaan Dan Loyalitas Nasabah Ditinjau Dari Perspektif Syariah (Studi Kasus Pada PT Bank BNI Syariah Cabang Makassar)", (Skripsi: Fakultas Ekonomi dan Bisnis Islam Universitas Islam Negeri Alauddin Makassar,2014), h. 80-81.

\section{DAFTAR PUSTAKA}

Bungin, Burhan. Metodologi Penelitian Kualitatif. Jakarta: Prenada Media Group, 2005.

Burhnai, MS. Kamus Ilmiah Populer. Jombang: Lintas Media, 2000.

Depdiknas. Kamus Besar Bahasa Indonesia.Jakarta :Balai Pustaka, 2001.

Griffin, Jill. Customer Loyalty Menumbuhkan dan Mempertahankan Kesetiaan Pelanggan, Alih Bahasa Dwi Kartini Yahya. Jakarta: Erlangga, 2005

Hamid, El-Qudah, Abdul. Kaum Luth Masa Kini. Jakarta: Yayasan Islah Bina Umat, 2015.

Hurriyati, Ratih. Bauran Pemasaran dan Loyalitas Konsumen. Bandung: Alfhabeta, 2010. 
J.F, Blackwell, dkk. Perilaku Konsumen. Terj. Jilid 1. Jakarta: Bina Rupa Aksara,1995.

Juwilda. Transgender: Manusia Keragaman dan Kesetaraannya. Bandung: Universitas Sriwijaya, 2010

Kartono, Kartini, Psikologi Abnormal dan Abnormalitas Seksual. Bandung: Mandar Maju, 1989

Kasmir, Etika Customer Service. Jakarta: Raja Grafindo, 2005

Koeswinarno, Hidup Sebagai Waria. Yogyakarta: PT LKiS Pelangi Aksara, 2004.

Pengaruh Ruang Sosial terhadap Waria serta Tinjauan Islam terhadapnya, Jurnal Penelitian Agama, Vol. XI, No. 2 Mei-Agustus 2002, Yogyakarta : Pusat Penelitian IAIN Sunan Kalijaga, 2002

Kotler, Philip. Manajemen Pemasaran. Jakarta:IKAPI, 2000

dan Keller, Kevin Lane. Manajemen Pemasaran, Edisi Ketiga Belas, Jilid 1. Jakarta: Erlangga, 2009

dan Amstrong, Gary. Prinsip-Prinsip Pemasaran, Jilid 1. Jakarta: Erlangga, 1997

Ma'hsum, Yahya dan Tyas, Roellya Arrdhyaninq. Bedanya Homoseksual dengan Waria, Jakarta. 2004.

Mangkunegara, A.P, Perilaku Konsumen, Edisi Revisi, Cetakan Keempat, Bandung: Refika Aditama, 2009.

Moleong, Lexy J. Metode Penelitian Kualitatif. Bandung: Remaja. Rosdakarya, 1994

Mulia, Siti Musdah. Islam dan Homoseksualitas; Membaca Ulang Pemahaman Islam, dalam Jurnal Gandrung, Vol.1, No.1, Juni 2010.

Nadia, Zunli. Waria Laknat atau Kodrat. Yogyakarta: Pustaka Marwa

Nevid, Jeffrey S. Psikologi Abnormal. Jakarta: Erlangga, 2003.

Paul, Peter J dan Olson, Perilaku Konsumen dan Strategi Pemasaran, Edisi ke Empat, Jilid I, Jakarta:Erlangga, 2006.

Purwadarminto, Kamus Umum Bahasa Indonesia. Jakarta: Balaik Pustaka, 1996.

Rambat, Lupiyoadi. Manajemen Pemasaran Jasa Teori dan Praktek. Jakarta: Salemba Empat, 2001 
Pri, Ramadhani H.US Rikanita,'Implementasi Corporate Social Responsibility Terhadap Kepercayaan Dan Loyalitas Nasabah Ditinjau Dari Perspektif Syariah (Studi Kasus Pada PT Bank BNI Syariah Cabang Makassar)" "Skripsi Fakultas Ekonomi dan Bisnis Islam Universitas Islam Negeri Alauddin Makassar,2014

Sa'abah, Marzuki Umar. Perilaku Seks Menyimpang dan Seksualitas Kontemporer Umat Islam. Jogjakarta : UII Press, 2001.

Susilo, Limakrisna Nanda. Manajemen Pemasaran. Jakarta: Amitra Wacana Media, 2012.

Tjiptono, Fandy. Pemasaran Jasa. Malang : Bayu Media, 2006.

, Strategi Pemasaran, Edisi Ketiga. Yogyakarta: Andi, 2008.

Yash, Transseksualisme: Sebuah Studi Kasus Perkembangan Transeksual Perempuan Ke Laki-Laki. Semarang:AINI, 2003. 